\title{
New challenges towards ecological management of Paliastomi Lake will significantly improve local environment with far-going global consequences
}

Grigol Abramia ( $\sim$ gia_abramia@hotmail.com )

International Center for Environmental Research

\section{Leil Gverdtsiteli}

The Environmental Engineering and Ecology Department Georgian Technical University

\section{Dimitri Eristavi}

The Environmental Engineering and Ecology Department Georgian Technical University

\section{Besik Kalandadze}

Department of Soil Geography, Iv. Javakhishvili Tbilisi State University

\section{Akaki Girgvliani}

Department of Computer Technologies Kutaisi State University

\section{Gero Weber}

Saarland University

\section{Ulrich Honecker}

Saarland University

Jochen Kubiniok

Saarland University

\section{Alexander Golijashvili \\ Biochimpharm}

Nana Japarashvili

Biochimpharm

\section{Article}

Keywords: regulations, water, waterfowl, pollution, environmental health, bacteriophages, monitoring, modeling, purification

Posted Date: September 24th, 2021

DOI: https://doi.org/10.21203/rs.3.rs-781103/v1

License: (c) (1) This work is licensed under a Creative Commons Attribution 4.0 International License. Read Full License 

New challenges towards the ecological management of Paliastomi Lake will significantly improve local environment with far-going global consequences

\author{
Dr. Grigol (Gia) Abramia* \\ Director \& CEO \\ International Center for Environmental Research (ICFER) \\ info@icfer.org
}

Prof. Dr. Leila Gverdtsiteli

The Environmental Engineering and Ecology Department

Georgian Technical University

1.gverdtsiteli@gtu.ge

Prof. Dr. Dimitri Eristavi

Head of Department

The Environmental Engineering and Ecology Department

Georgian Technical University

d.eristavi@gtu.ge

Prof. Dr. Besik Kalandadze

Department of Soil Geography,

Iv. Javakhishvili Tbilisi State University,

kalandabeso@gmail.com

Prof. Akaki Girgvliani

Department of Computer Technologies

Kutaisi State University

akaki1954@gmail.com

Dr.Gero Weber

Position: Researcher

Affiliation: Physical Geography and Environmental Research, Saarland University, Am Markt Zeile 2, 66125

Saarbrücken, Germany

E-Mail: gero.weber@geo.uni-saarland.de

Dr.Ulrich Honecker

Position: Researcher

Affiliation: Physical Geography and Environmental Research, Saarland University, Am Markt Zeile 2, 66125

Saarbrücken, Germany

E-Mail: ulrich.honecker@geo.uni-saarland.de

Prof. Dr. Jochen Kubiniok

Position: Researcher, head of department

Affiliation: Physical Geography and Environmental Research, Saarland University, Am Markt Zeile 2, 66125

Saarbrücken, Germany

E-Mail: j.kubiniok@mx.uni-saarland.de

Alexander Golijashvili-Microbiologist

Position: Director, Microbiologist

Affiliation: Company Biochimpharm, Tbilisi, Georgia

E-Mail: biochimpharm@geophage.ge 
Nana Japarashvili

Position: Microbiologist

Affiliation: Company Biochimpharm, Tbilisi, Georgia

E-Mail: n.japarashvili@geophage.ge 
Abstract

The publication is addressing the problems of pollution from agricultural sources; municipal wastewater and industry in line with the bacterial pollution caused by migratory waterfowl of Paliastomi Lake that is an internationally recognized habitat, wintery and transit area of the birds and an important tourism site. It reviews: the current state of the environment of Paliastomi Lake at the moment of the chemical and microbiological research and mathematical simulation modeling of possible dissemination of polluting chemicals and bacterial pathogens; pollution by nutrient-rich water causing large blooms of algae and aquatic plants that in its turn leaves little oxygen for fish and other aquatic animals, resulting in the eutrophication followed by suffocation of aquatic life.

Keywords: regulations, water, waterfowl, pollution, environmental health, bacteriophages, monitoring, modeling, purification 


\section{Introduction}

The Greek geographer, philosopher, and historian Strabo (64 or 63 BC-1- c. AD 24) was the first to mention Paliastomi Lake: "The Phasisi (river Rioni) flows into the Ponto" (Black Sea). Colchis Commercial is a city on the Phasisi River with the same name. Agathias Scholasticus (ca. 532-580), a Greek historian, records the existence of a lake at the Rioni River's mouth. The meaning of: "Paliastomi derives from Greek language: Palaeo - old; Stoma - pore, hollow [1].

Paliastomi Lake ( Figure 1) is a protected area of international importance, according to the Ramsar Convention, and is part of the Kolkheti National Park (Figure 2). It encompasses a total of 33,710 acres in the center area of the Black Sea coastal alluvial plain, in the administrative regions of Khobi and Lachkhuti, as well as the territory of the city of Poti $(55,500$ ha including the marine part). The site is home to a diverse range of relict and unique flora and wildlife. Waterfowl of many species winter at the site [2].

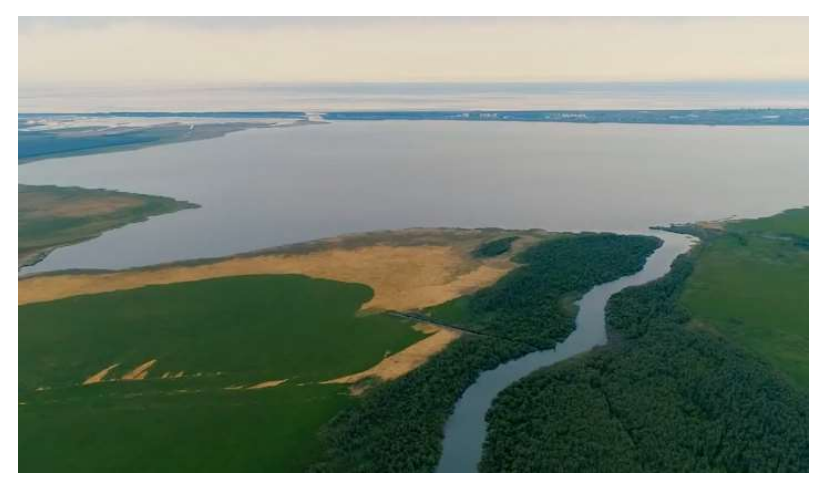

Figure 1, 2020 Lake Paliastomi

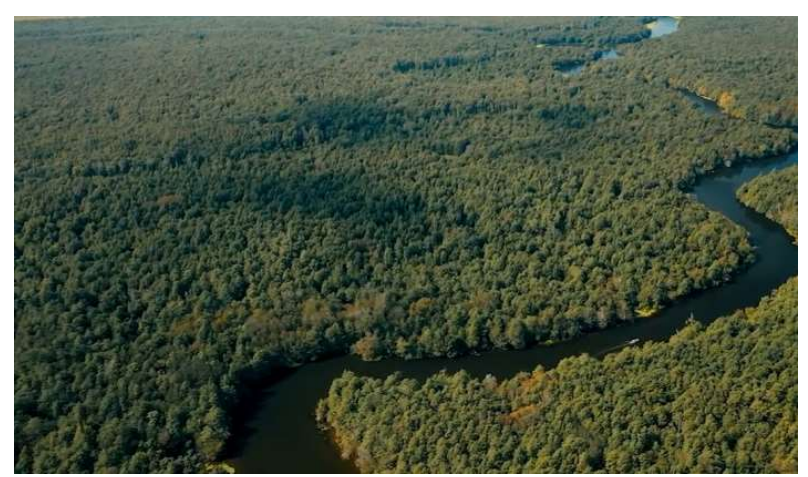

Figure 2, 2020 Kolkheti National Park

The area and its biodiversity are protected by the international conventions (Biodiversity, Ramsar, Bonn, Black Sea) and the national legislation harmonized with EU aquis in accordance with EU-Georgia AA. Its surface area is $17.3 \mathrm{~km}^{2}$ and its mean depth is $2.6 \mathrm{~m}$ (See Figure 3).

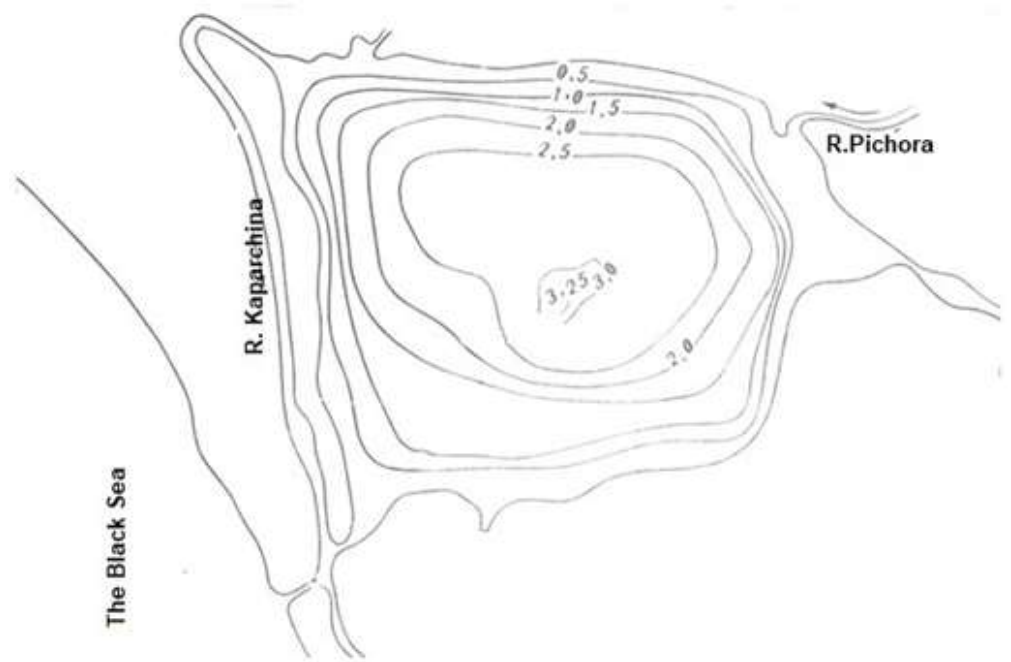

Figure 3, Paliastomi Lake Bathymetry [2].

The impact of ecological factors caused Paliastomi lake salination with associated changes in water hydrology, dramatic decrease in composition of the lake biodiversity (the number of fish species decreased from 40 to 24$)$. 
The Lake is fed by rain water and tributaries. High water levels are common in spring, summer and fall, while in winter the water level is low. The water is warm in July and August $\left(25.1^{\circ} \mathrm{C}\right)$ and is cold in winter $\left(5.2^{0} \mathrm{C}\right)$. Due to strong winds, homothermia is quite frequent on the Lake (see Figure 4).

Paliastomi Lake is separated from the Sea by the 300-400-meter-wide and 2-meter-high sand-bar. Sedimentation and extensive vegetation development plague the lake. Rivers are controlled by flood banks in wetter locations. The rivers (Pichora, Tkhorikna, and others) and lakes (Paliastomi, Imnati, Maltakva, and others) receive water from a large watershed, and water levels in marshes, lakes, and rivers range from 0.2 to 0.7 meters, 0.5 to 3 meters, and 1 to 21 meters. Paliastomi Lake was a freshwater lake until 1924, with water draining into the Kaparchina River, which begins on the lake's northwest shore. Because the River Kaparchina's capacity was insufficient to adequately drain all of the floodwater from the Lake, the level of Paliastomi Lake (see Figure 1) increased swiftly during the heavy rain and flooded about $40 \mathrm{~km} 2$ of the area, incl.

To protect Poti from periodic flooding, in 1924 a canal was built to connect the southwestern part of the Lake with the Sea After some time, powerful storms eroded the canal and it was replaced by a strait, 1.5 $\mathrm{km}$ long, 140-150 m wide and 3-4 m deep watercourse. Sea water freely enters the through this strait during the heavy storms, and this has salinized the Lake: before the strait was excavated, the lake's salinity used to be $1 \%$; now it's $12-13 \%[3]$.

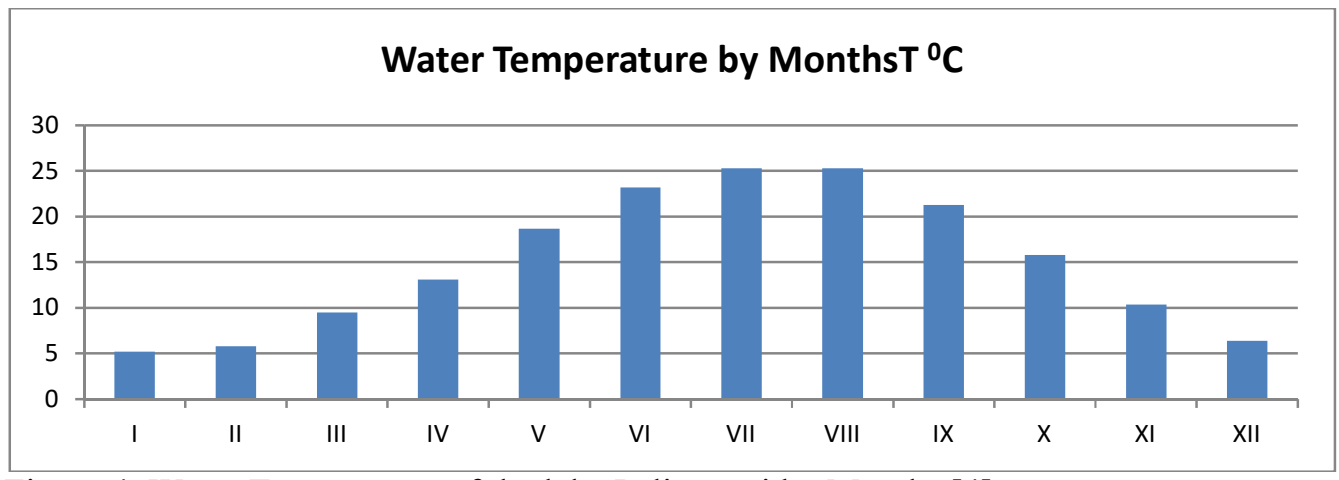

Figure 4, Water Temperature of the lake Paliastomi by Months [4]

The amount of annual atmospheric precipitation in the Kolkheti lowlands ranges from 1200-2800 $\mathrm{mm}$, and the modulus of groundwater runoff pressure is $41 / \mathrm{s}$ from $1 \mathrm{~km}^{2}$.

More than 300 different bird specimens are described. The Lake is visited more than 100 different migratory birds and their total number is more than 40000 . When the surface of the Azov Sea freezes, their number increases significantly [5].

Large blooms of algae and aquatic plants develop from nutrient-rich water pollution, leaving little oxygen for fish and other aquatic species, resulting in eutrophication and aquatic life suffocation. The overabundance of nutrients (nitrogen and phosphorus) in seas, lakes, rivers, and streams can cause eutrophication, a set of negative consequences. [6].

Paliastomi Lake is used as a cultural leisure zone. It also serves as an important tourist and recreational facility.

In the North-eastern part of the Lake, the Pichora River flows into the Lake crossing a large area of Western Georgia's agrarian settlements and significantly pollutes the Lake with nutrients. Another significant source of Paliastomi Lake pollution is so called "Airport Chanel" that is one of the main 'collectors' of sewage water in the city of Poti. The source is located at the North-eastern part of the Lake close to the fish factory that also pollutes the Lake, but only in November and December in anchovy fishing season .

The process of fish meal production involves the hydraulic discharge of fishes with loss of soluble proteins to the Sea [7]. Recycling the water used to unload fish from ships to factories will reduce the environmental impact [8]. These recycled fishmeal waste waters have high content of chemical oxygen demand (COD) protein and salinity (sodium, chloride, sulphate) [7, 9]. 
In recent years, fisheries have often been depleted, which, according to the Environmental Protection Agency of Georgia, is caused by the lack of oxygen in water that is the result of the process of eutrophication in Paliastomi Lake [10].

Carnivorous activity or environmental contamination can cause infection in wild birds. Carnivorous and omnivorous wild birds are the most usually affected, as they eat food that may be contaminated, such as intestine, eat food that has fallen to the ground, or feed or live in contaminated water [11].

Salmonella spp. are known to be reservoirs in wild birds [11]. Salmonella has been discovered occasionally in the gut flora of wild birds in previous studies [12].

\section{Results}

\section{Chemical microbiological analysis of the water of Paliastomi Lake}

On May 14-15, 2017, an expedition to conduct chemical analysis of the chemical, microbiological and seabed sediments of Paliastomi Lake was organized. We selected four analysis and sampling points near Paliastomi Lake, adjacent to Collinbari Island: 1. Rangers' Base-1. 100 meters offshore from the ranger base; 2 Rangers' Base-2, at $100 \mathrm{~m}$, from the base; Rangers' Base-3, at $500 \mathrm{~m}$ from Ranger base; and ranger base-4 near the fish processing plant, $150 \mathrm{~m}$ from the factory exit channel (Figure 5) [13].

Figure 5, Chemical pollution (14-15 May, 2017)

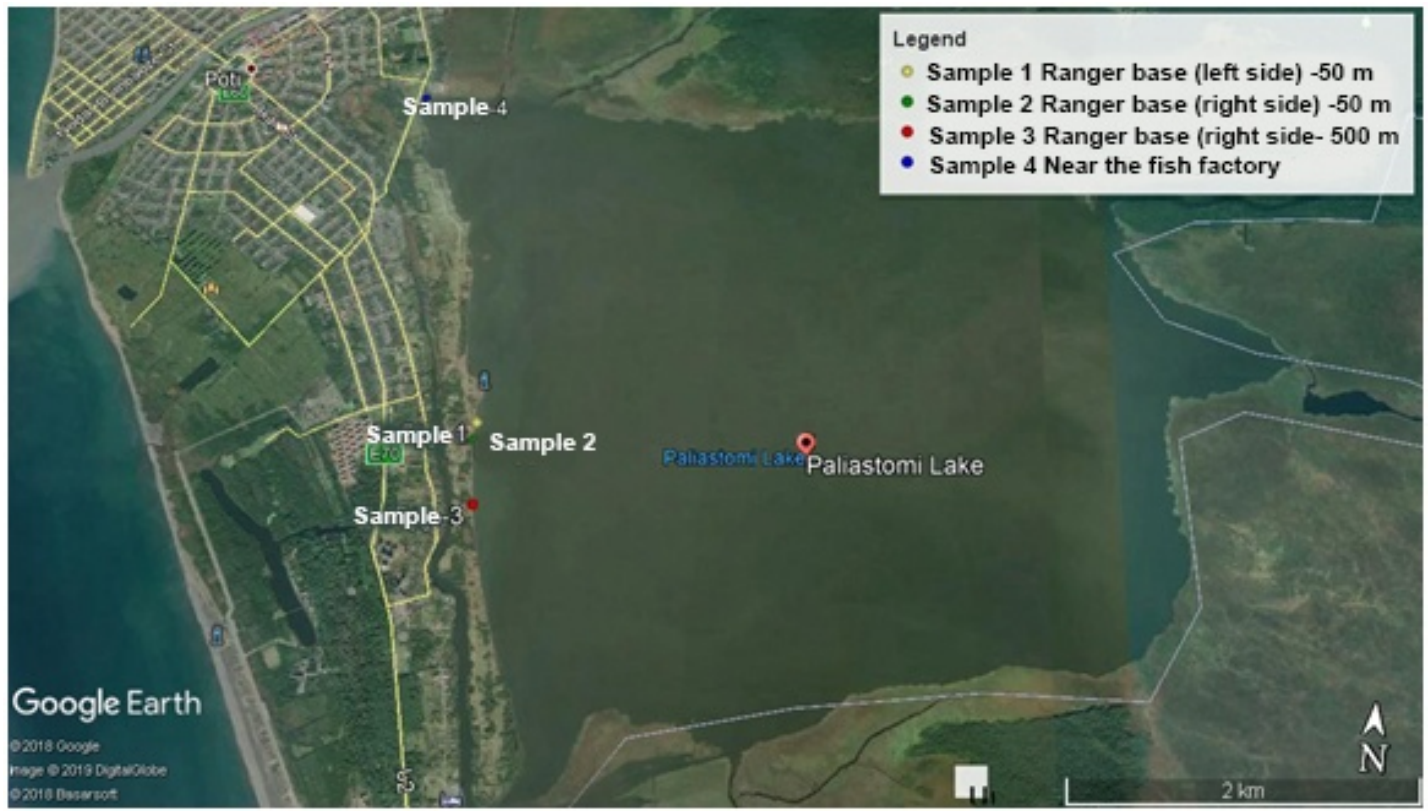

Paliastomi Lake water and seabed sampling, preservation, storage and transportation was done using ISO standard methods. The chemical properties of water organoleptic, chemical and microbiological indicators as well as seabed sediments were determined by field portable apparatus and stationary laboratory using ISO and GOST standard methods $[15,116]$.

The $\mathrm{pH}$ value of Paliastomi Lake water is slightly more than pronounced due to the nature of the salts dissolved in it and the hydrolysis. According to samples 1, 2 and 3, the oxygen content is high at 7.3-7.8 $\mathrm{mg} /$ $\mathrm{L}$, and the amount of oxygen dissolved according to the 4th data is relatively low and equals to $3.6 \mathrm{mg} / \mathrm{L}$. The oxygen regime has a profound effect on the life-ability of the reservoir, the minimum dissolved oxygen content that ensures normal fish development is $5 \mathrm{mg} / 1 \mathrm{O}_{2} / \mathrm{L}$, and its reduction to $2 \mathrm{mg} / \mathrm{L}$ results in massive fish mortality [5,9]. The concentration of dissolved oxygen in samples 1,2 and 3 corresponds to class II-purified class of surface water quality, and class 4 is classified as contaminated, class 4 . 
Waterbed sediments are formed as a result of deterioration of catchment rocks and soil cover following the soil surface washing. The composition of waterbed sediments in the Lake basin is regularly altered by constructing rocks in accordance with lithology and grain size [17, 18]. In addition, as a result of sedimentation of minerals and organic matter in the Lake water, the water flows into the Lake and produces sediment on its bed. According to the literature, heavy metal contamination of seabed sediments is mainly caused by anthropogenic sources, residues of agriculture and enterprises working in various industries [17, $18]$.

Paliastomi Lake sediments were sampled and studied (by ISO methods) in May of 2017 . Based on the geochemical background, the results of the analysis, the total copper content in the bottom sediments of Paliastomi Lake is lower than the permissible rates $[2,15,19,20]$, and exceeds the permissible values in Georgia $[2,18]$. Lead and zinc content in Lake sediments may be considered as a natural background $[2,18]$. The content of manganese and iron in the seabed is less than the MPC.

\section{Results of the microbiological analysis of Paliastomi Lake water and waterbed sediments}

Since Paliastomi Lake is used for fishing, as well as for cultural recreation and swimming, it is necessary to determine the microbiological contamination of water causing various infectious diseases in order to maintain the necessary degree of the Lake water purity and ecological control.

There are very limited bacterial research data for Paliastomi Lake found in literary sources.

On May of 14-15 and August 9-10 of 2017, an expedition to collect microbiological samples of Paliastomi Lake was organized by International Center for Environmental Research (ICFER). On March 29 and April 18, 2018, the Lake water and bed samples were collected for microbiological analysis by ICFER. Besides, on January 30, 2019, the Lake water samples were taken for microbiological analysis by ICFER.

Lake water sampling, storage, transports and microbiological analysis was performed according to international ISO and GOST standards.

\section{Tests of surface water and Lake bed sediments}

The bicrobiological analysis determined the total coliforms and the number of coli-forming bacteria in the intestinal tract. In samples 1, 2 and 4, the total coliforms are sufficiently high and in $100 \mathrm{ml}$ of water they are 3000, 1280, $5000 \mathrm{CFU}$, while in the third sample, their number is $920 \mathrm{CFU} / 100 \mathrm{ml}$ respectively. Ecoli-grade bacteria were found in water samples 2 and 4, with a mean value of 100-40 ml per $100 \mathrm{ml} 20-40$ CFU (See Table 2). Their numbers increase with the migration of migratory birds in October and May.The total water content of the open water reservoirs - mesophilic aerobes and facultative anaerobic microorganisms (MAFA) as per the permitted norm in $1 \mathrm{ml}$ is no more than $1000 \mathrm{CFU}$, while in 1, 2 and 3 water samples the total amount of MAFA varies from 800 to $5000 \mathrm{CFU} / \mathrm{ml}$, and the maximum value (3500 $\mathrm{CFU} / \mathrm{ml}$ ) is reached in the 4 th sample (See Table 1).

Table 1 Microbiological analysis of Paliastomi Lake water (August 10, 2017)

\begin{tabular}{|c|c|}
\hline \multicolumn{2}{|l|}{ Microbial quality indicators of Paliastomi Lake water: } \\
\hline \multicolumn{2}{|l|}{ Used Standard: ГОСТ N 18963-73 } \\
\hline \multicolumn{2}{|l|}{ Site: N1 R. Kaparchina-Adjacent territory to the Bridge } \\
\hline \multicolumn{2}{|l|}{ Microbial quality indicators of the site water } \\
\hline $\begin{array}{l}\text { Outdoor reservoir water quality index MAFA actual } \\
\text { rate by ND. Not more then }\end{array}$ & $1000 \mathrm{CFU} / \mathrm{ml}$ \\
\hline Total quality of MAFA $/ \mathrm{ml}$, MAFA actual rate & $5000 \mathrm{CFU} / \mathrm{ml}$ \\
\hline
\end{tabular}




\begin{tabular}{|c|c|}
\hline $\begin{array}{l}\text { Indicator of water quality (coli-titer; coli-index ) by } \\
\text { ND }\end{array}$ & $\begin{array}{l}\text { coli-titer }<0,4 \text {; not less }-111 \text {, coli-index; } \\
\text { not more- } 9\end{array}$ \\
\hline $\begin{array}{l}\text { Actual indicator of the quality of open water } \\
\text { reservoir: coli-titer and coli-index: } 100 \mathrm{ml}, 10 \mathrm{ml}, 1 \\
\mathrm{ml}, 0,1 \mathrm{ml} \text { (Total volume of water } 111 \mathrm{ml} \text { ); }\end{array}$ & $\begin{array}{l}\text { coli-titer }<0,4 \\
\text { coli-index }>2380\end{array}$ \\
\hline $\mathrm{pH}$ & 6,6 \\
\hline \multicolumn{2}{|l|}{ Site: N 2 Rangers Base right site } \\
\hline \multicolumn{2}{|l|}{ Microbial quality indicators of the site water } \\
\hline $\begin{array}{l}\text { Outdoor reservoir water quality index MAFA actual } \\
\text { rate by ND. Not more then }\end{array}$ & $1000 \mathrm{CFU} / \mathrm{ml}$ \\
\hline Total quality of MAFA $/ \mathrm{ml}$, MAFA actual rate & $1000 \mathrm{CFU} / \mathrm{ml}$ \\
\hline $\begin{array}{l}\text { Indicator of water quality (coli-titer; coli-index ) by } \\
\text { ND }\end{array}$ & $\begin{array}{l}\text { coli-titer not less -111, coli-index; not } \\
\text { more -9 }\end{array}$ \\
\hline $\begin{array}{l}\text { Actual indicator of the quality of open water } \\
\text { reservoir: coli-titer and coli-index: } 100 \mathrm{ml}, 10 \mathrm{ml}, 1 \\
\mathrm{ml}, 0,1 \mathrm{ml} \text { (Total volume of water } 111 \mathrm{ml} \text { ); }\end{array}$ & $\begin{array}{l}\text { coli-titer }-4 \\
\text { coli-index }-230\end{array}$ \\
\hline $\mathrm{pH}$ & 6,5 \\
\hline \multicolumn{2}{|l|}{ Site: N 3Rangers Base left site } \\
\hline \multicolumn{2}{|l|}{ Microbial quality indicators of the site water: } \\
\hline $\begin{array}{l}\text { Outdoor reservoir water quality index MAFA actual } \\
\text { rate by ND. Not more then }\end{array}$ & $1000 \mathrm{CFU} / \mathrm{ml}$ \\
\hline Total quality of MAFA/ml, MAFA actual rate & $1000 \mathrm{CFU} / \mathrm{ml}$ \\
\hline $\begin{array}{l}\text { Indicator of water quality (coli-titer; coli-index ) by } \\
\text { ND }\end{array}$ & $\begin{array}{l}\text { coli-titer not less 111, coli-index; not } \\
\text { more -9 }\end{array}$ \\
\hline $\begin{array}{l}\text { Actual indicator of the quality of open water } \\
\text { reservoir: coli-titer and coli-index: } 100 \mathrm{ml}, 10 \mathrm{ml}, 1 \\
\mathrm{ml}, 0,1 \mathrm{ml} \text { (Total volume of water } 111 \mathrm{ml} \text { ); }\end{array}$ & $\begin{array}{l}\text { coli-titer-4 } \\
\text { coli-index }-230\end{array}$ \\
\hline $\mathrm{pH}$ & 6,5 \\
\hline \multicolumn{2}{|l|}{ Site: Adjacent territory of the Island Kolimbari } \\
\hline \multicolumn{2}{|l|}{ Microbial quality indicators of the site water: } \\
\hline $\begin{array}{l}\text { Outdoor reservoir water quality index MAFA actual } \\
\text { rate by ND. Not more then }\end{array}$ & $1000 \mathrm{CFU} / \mathrm{ml}$ \\
\hline \multicolumn{2}{|l|}{ Total quality of MAFA $/ \mathrm{ml}$, MAFA actual rate } \\
\hline $\begin{array}{l}\text { Indicator of water quality (coli-titer; coli-index ) by } \\
\text { ND }\end{array}$ & $1000 \mathrm{CFU} / \mathrm{ml}$ \\
\hline $\begin{array}{l}\text { Actual indicator of the quality of open water } \\
\text { reservoir: coli-titer and coli-index: } 100 \mathrm{ml}, 10 \mathrm{ml}, 1 \\
\mathrm{ml}, 0,1 \mathrm{ml} \text { (Total volume of water } 111 \mathrm{ml} \text { ); }\end{array}$ & $\begin{array}{l}\text { Coli-titer not less -111, coli-index; not } \\
\text { more -9 }\end{array}$ \\
\hline $\begin{array}{l}\text { Outdoor reservoir water quality index MAFA actual } \\
\text { rate by ND. Not more then }\end{array}$ & $\begin{array}{l}\text { coli-titer- } 0,4 \\
\text { Coli-index- } 2380\end{array}$ \\
\hline $\mathrm{pH}$ & 6,8 \\
\hline
\end{tabular}

The open water reservoir water quality index (coli titer, coli index) shall be as follows: coli -titer not less than $111 \mathrm{ml}$ and coli-index not more than 9 .

Coli index in water samples 1 and 4 , at $\mathrm{pH}=6.6$ and $\mathrm{pH}=6.8$, was more than 2380 and coli index was less than 0.4. In the second and third samples, at $\mathrm{pH}=6.5$, the coli titre was reduced to 4 and the coli index was 230 (See Table 2). Therefore, high levels of bacterial contamination of the Lake water should be caused not only by the contamination of Paliastom Lake, but also by sewage discharges (directly into the Lake, without any treatment) from internally displaced persons' shelter and open landfills adjacent to it.

In January 292018 has been taken water sample from the lake Paliastomi in 50 meters right from Rangers's base (latitude 42.11842; longitude 41.70293) for the purification by bacteriophages. 
The microbiological analyses shown that total amount of MAFAN in the water constituted 1500 $\mathrm{CFU} / \mathrm{ml}$ when the permissible norms is not more than $1000 \mathrm{CFU} / \mathrm{ml}$.

In an open water reservoir quality indicator (coli-titer and coli-index) MAC is following: coli-titer111, coli-index-9. During the condition when $\mathrm{pH}=6,8$ coli-titer -4 and coli-index was 230 . Total amount of E-coli constituted $1 \times 10^{3}$, but MAFAN equaled $1500 \mathrm{CFU} / \mathrm{ml}$ (See Table 3 ).

We used water sample as a model pattern for the bacterial treatment with bacteriophage cocktail (BC-1-1) (Shigella flexneri 1, 2, 3, 4, 6 serological group; Shigella sonnei; Salmonella paratyphi A; Salmonella paratyphi B; Salmonella typhimurium; Salmonella choleraesuis; Salmonella oranienburg; Salmonella enteritidis;; enteropathogenic E. coli different serological groups; Proteus; Enterococcus; Staphylococcus; Pseudomonas aeruginosa).

Table 2 Microbiological analysis of Paliastomi Lake water (29March, 18April, 2018)

\begin{tabular}{|c|c|c|c|}
\hline \multicolumn{4}{|c|}{ Test Name: Fish factory adjacent to Airport Channel(42 $\left.{ }^{\circ} 7^{\prime} 4.51^{\prime \prime} \mathrm{N} 41^{\circ} 42^{\prime} 11.51^{\prime \prime} \mathrm{E}\right)$} \\
\hline \multirow[t]{2}{*}{ Testing parameters } & \multicolumn{3}{|l|}{ Evaluation criteria } \\
\hline & $\begin{array}{l}\text { Significance of Indicators by } \\
\text { ND }\end{array}$ & \multicolumn{2}{|c|}{$\begin{array}{l}\text { The actual meaning of } \\
\text { the indicator by } \\
\text { confidence }\end{array}$} \\
\hline MAFA meaning & - & \multicolumn{2}{|c|}{$37^{0} \mathrm{C}-65 ; 22^{0} \mathrm{C}-228$} \\
\hline Total coliforms $1000 \mathrm{ml}$ & - & \multicolumn{2}{|c|}{6000} \\
\hline E-coli, $1000 \mathrm{ml}$ & $\leq 10000$ & \multicolumn{2}{|l|}{70} \\
\hline (S.faecalis) $100 \mathrm{ml}$ & - & \multicolumn{2}{|l|}{29} \\
\hline (Cl.perfringens ) per $100 \mathrm{ml}$ & - & \multicolumn{2}{|l|}{4} \\
\hline $\begin{array}{l}\text { Pathogenic organisms, including } \\
\text { salmonids } 100 \mathrm{ml}\end{array}$ & - & \multicolumn{2}{|c|}{ Not detected } \\
\hline Coliphages $1000 \mathrm{ml}$ & $\leq 100$ & \multicolumn{2}{|c|}{ Not detected } \\
\hline S.Aureus $100 \mathrm{ml}$ & - & \multicolumn{2}{|c|}{320} \\
\hline \multicolumn{4}{|c|}{ 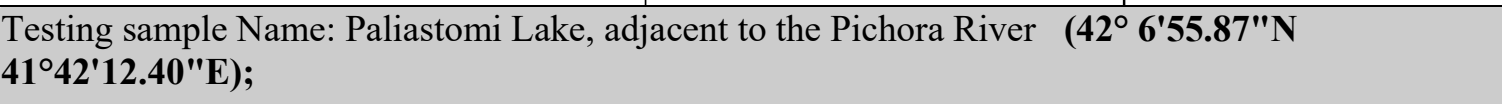 } \\
\hline Total coliforms, $1000 \mathrm{ml}$ & - & & 7200 \\
\hline \multirow[t]{2}{*}{ Testing parameters } & \multicolumn{3}{|c|}{ Evaluation criteria } \\
\hline & \multicolumn{2}{|l|}{ Significance of Indicators by ND } & $\begin{array}{l}\text { The actual } \\
\text { meaning of the } \\
\text { indicator } \\
\text { confidence }\end{array}$ \\
\hline E-coli, $1000 \mathrm{ml}$ & \multicolumn{2}{|l|}{$\leq 10000$} & 6000 \\
\hline Coliphages, $1000 \mathrm{ml}$ & \multicolumn{2}{|l|}{$\leq 100$} & 700 \\
\hline \multicolumn{4}{|c|}{ Ranger Base, left side $(100 \mathrm{~m})\left(42^{\circ} 8^{\prime} 5.08^{\prime \prime} \mathrm{N} 41^{\circ} 45^{\prime} 2.24^{\prime \prime} \mathrm{E}\right)$; } \\
\hline Quantity of E-coli in 1 gram & \multicolumn{2}{|l|}{ E-coli CFU/g } & (St.faecalis) \\
\hline 375 & \multicolumn{2}{|l|}{300} & 12 \\
\hline \multicolumn{4}{|l|}{ Clean } \\
\hline- & \multicolumn{2}{|c|}{$1-9$} & $1-9$ \\
\hline$P$ & & & \\
\hline
\end{tabular}




\begin{tabular}{|c|c|c|}
\hline- & $>10$ & $>10$ \\
\hline \multicolumn{3}{|c|}{ Ranger Base, right side $(100 \mathrm{~m})\left(\mathbf{4 2}^{\circ} \mathbf{8}^{\prime} \mathbf{2 4 . 5 1} 1^{\prime \prime} \mathbf{N 1}^{\circ} \mathbf{4 2} 2^{\prime} 17.02^{\prime \prime} \mathrm{E}\right)$} \\
\hline Study Parameters & ND Indicators & $\begin{array}{l}\text { The actual value } \\
\text { of the indicator }\end{array}$ \\
\hline Total coliforms $1000 \mathrm{ml}$ & - & 7200 \\
\hline E-coli, $1000 \mathrm{ml}$ & $\leq 10000$ & 6000 \\
\hline Coliphages $1000 \mathrm{ml}$ & $\leq 100$ & 700 \\
\hline
\end{tabular}

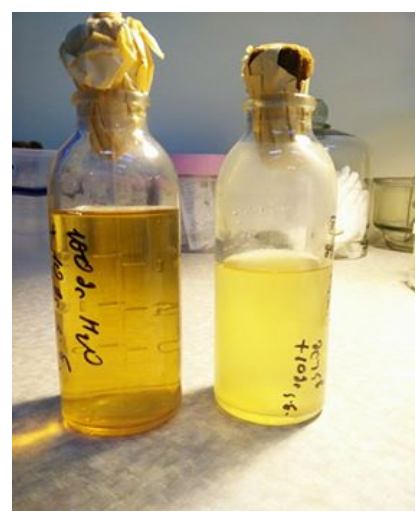

The $\mathrm{BC}-1$ contained viruses of the bacteria (bacteriophages) that directly affect their host bacteria, so the BC-1 was used to treat Lake Paliastom water, reducing the amount of E-coli to $2 \times 10^{2} \mathrm{CFU} / \mathrm{ml}$ ( See figure 6). The amount of MAFAN $/ \mathrm{ml}$ reduced to $600 \mathrm{CFU} / \mathrm{ml}$. We considered the experiment successful, as during the processing of the lake water sample its bacterial contamination was reduced by $60 \%$ (See Table 3).

Figure 6, Lake Paliastomi water samples (original-right and after treatmen-left by BC-1). Teble 3 Results of the bacterial purification of the lake Paliastomi water by BC-1

\begin{tabular}{|c|c|c|}
\hline \multicolumn{3}{|c|}{ Microbiological quality indicators of the water of lake Paliastomi } \\
\hline \multicolumn{2}{|l|}{ Sampling location: } & $\begin{array}{l}\text { Lake Paliastomi Rangers Base - } \\
(42.11842 ; 41.70293)\end{array}$ \\
\hline \multicolumn{2}{|l|}{$\mathrm{pH}$} & 6,8 \\
\hline \multicolumn{2}{|l|}{ MAFAN /ml by ND } & Not more then $1000 \mathrm{CFU} / \mathrm{ml}$ \\
\hline \multicolumn{2}{|c|}{ MAFAN/ml actual rate } & $1500 \mathrm{CFU} / \mathrm{ml}$ \\
\hline \multicolumn{2}{|c|}{ Total MAFAN /ml after treatment with BC-1 } & $600 \mathrm{CFU} / \mathrm{ml}$ \\
\hline \multicolumn{2}{|c|}{ Water quality indicator (coli-titer, coli-index) by ND } & $\begin{array}{l}\text { Coli-titer } 111 \text {, } \\
\text { Coli-index not more then- } 9 .\end{array}$ \\
\hline \multicolumn{2}{|c|}{$\begin{array}{l}\text { Actual rate coli-titer, coli-index : } 100 \mathrm{ml}, 10 \mathrm{ml}, 1 \mathrm{ml}, 0,1 \mathrm{ml} \\
\text { (total amount of water } 111 \mathrm{ml} \text { ). }\end{array}$} & $\begin{array}{l}\text { Coli-titer }-4 \\
\text { Coli-index } 230 .\end{array}$ \\
\hline \multirow[t]{2}{*}{ E.coli-quantity/ml } & In original water sample & $1 \times 10^{3} \mathrm{CFU} / \mathrm{ml}$ \\
\hline & In treated water sample & $2 \times 10^{2} \mathrm{CFU} / \mathrm{ml}$ \\
\hline \multicolumn{2}{|l|}{ Used Standard: } & ГОСТ-№18963-73 \\
\hline
\end{tabular}


For in-depth study of bacteriophage treatment technology for microbiological contamination of Lake Paliastomi water, samples were taken at the following facilities:

- March 21, 2019 Paliastom Lake water samples 50 meters to the right of the Ranger base;

- In the vicinity of the fish factory near the bridge.

The microbiological quality of the water was assessed according to the requirements for standard drinking water and Category 2 surface water.

Examined water according to general microbial parameters gives the typical picture of natural open water reservoirs with moderate degree of pollution. Relatively high rates of total microbial quantity $\left(22^{\circ} \mathrm{C}\right)$ and fecal contamination (by total coliforms). No coliform content was observed. However high content of vibrios and aeromonas was detected. See the results of the study in the table. 2-2-isolates of fecal coliforms, enterococci, vibrios, and salmonellae were removed (Table 4).

According to the Table 4, the general microbial parameters, the test water gives the characteristic picture of natural open water reservoirs (with small - moderate pollution). The rates of total microbial count $\left(22^{\circ} \mathrm{C}\right)$ and fecal contamination (namely total coliforms) are relatively high, although coliform content was not detected. The number of salmonella is relatively high. 2-2 isolates of fecal coliforms, enterococci, vibrios, and salmonella were sowed. The reason of low bacterial pollution might have been caused by 2 reasons: the fish factory was closed and it was not the period of waterfowl migration.

Table 4 Consequences of determining phage susceptibility

\begin{tabular}{|c|c|c|c|c|c|c|c|}
\hline Phages & ú & 岂 & ú & $u_{\infty}^{+1}$ & in & $\begin{array}{l}0 \\
u \\
u\end{array}$ & 峁 \\
\hline Salmonella (Ranger base) & + & - & - & - & - & - & - \\
\hline Vibrio (Ranger base) & - & - & - & - & - & - & - \\
\hline E.coli (Ranger base) & + & - & - & - & - & + & - \\
\hline Salmonella (Fish factory) & + & - & - & - & - & - & - \\
\hline Vibrio (Fish factory) & - & - & - & - & - & - & - \\
\hline E.coli (Fish factory) & - & - & - & - & - & + & - \\
\hline
\end{tabular}

„+"Notes a weak lysis reaction

BC-2 causes lysis of following bacteria: Streptococcus, Staphilococcus, E.Coli, Pseudomanas aeruginosa, Proteus;

BC-3 causes lysis of following bacteria: S.aureus, S.epidermidis, S.pyogenes, S.sanguis, S.salivarius, S.agalactiae;

BC-4 causes lysis of following bacteria: S.aureus; 
BC-5 causes lysis of following bacteria: Streptococcus, Staphyloccccus, Escherichia coli, Pseudomonas aeruginosa, Proteus ;

BC-6 causes lysis of following bacteria: Shigella flexneri 1.2.3.4 and Shigella zonnei, S.typhimurium, S.enteritidis, S.newport, S.heidelberg, S.cholera suis S.oranienburg, S.dublin, S.anatum;

BC-7 causes lysis of following bacteria: S.aureus da S.epidermidis, S.pyogenes, S.sanguis, S.salivarius, S.agalactiae, E.coli.

In 30.082004 instruction on preventive- treatment and water purification by phages preparations against salmonella bacteria was approved by the State Veterinary Department of Georgia.

The BC-1 was tested within the WB Georgian Agriculture Development Program's Project implemented by ICFER-CGS 03-70 "Demonstration and application of achievement of environmentally friendly and efficient technology on the use of treatment-preventive veterinary biopreparation of bacteriophages against antibiotic resistant salmonella infections in poultry."

Chicken is given BC-1 a preparation with water and food as a prophylactic medicine. As a precaution, 10 milliliters of drinking water are mixed with 10 milliliters of BC-1 before being given. Birds are fed 2 milliliters in 10 milliliters of water for treatment purposes. For preventive measures, 1 milliliter of food-safe preparation is mixed with 1 milliliter water and sprayed on 20 grams of food. In terms of treatment, 1 milliliter of BC-1 is combined into 10 milliliters of food. The food is vigorously churned and fed to the birds to ensure an even distribution of preparation in the food. The chicken is given the preparation once a day in the morning. The preventive course lasts about 4-5 days. The treatment lasts 7-8 days. The average preventive daily dose for a $0-60$-day-old chicken is 2X106, or 4X106 for 180-day-old chickens, and 8X106 for chickens older than 180 days. In the event of an epidemic, however, the use of antibiotics is not prohibited.

We suggest to adapt the proven methodology to wild birds, and do not exclude the possibility of conducting a study to apply the methodology in aquaculture in the marine of freshwater cages, however, in this case, we advocate that fish food should be processed with a specially compiled bacteriophage cocktail, which, if necessary, would not exclude the complex use of bacteriophages with antibiotics, which will significantly reduce the proportion of their use in aquaculture.

\section{Water Pollution Modeling}

The dissemination of pathogenic bacteria in the lake water was modeled. The following data is required to develop this model system:

- Hydrodynamic characteristics of the water depths;

- Water level;

- $\quad$ Wind velocity;

- Bacterial contamination points;

- $\quad$ Bacterial monitoring;

- $\quad$ Number of common coliforms.

For computational modeling of metals and coliform dissemination in Lake Paliastomi, a twodimensional numerical model based on the system of integration by vertical integration of water motion and continuity equations was used $[20,21]$. The program was compiled in Visual $\mathrm{C}++$. The model is based on the integration of the two-dimensional flow dynamics of the Lake and passive impedance in the water area using a modern high-resolution numerical scheme. In the integration process, the method of visualizing the results is applied. 
The following parameter values were used in the model: Gravitational constant $G=980 \mathrm{~cm} / \mathrm{sec}^{2}$, Coriolis setting $\mathrm{f}=0.9510-04 \mathrm{sec}-1$, Friction strain vector at the bottom $\tau^{\rightarrow 1}\left(\tau \frac{1}{\mathrm{x}}, \tau \frac{1}{\mathrm{y}}\right)$ calculated by formulas: $\tau \frac{1}{\mathrm{x}}=\mathrm{b} \cdot \sqrt{u^{2}+v^{2}} \cdot \mathrm{u}$

$$
\tau \frac{1}{\mathrm{y}}=\mathrm{b} \cdot \sqrt{u^{2}+v^{2}} \cdot \mathrm{v}
$$

where $b=0,003$

Atmospheric wind friction tension vector $\tau \rightarrow 0\left(\tau \frac{0}{\mathrm{x}}, \tau \frac{0}{\mathrm{y}}\right)$ calculated by formulas:

$$
\begin{aligned}
& \tau \frac{0}{x}=b 1 \cdot \sqrt{W \frac{2}{x}+W \frac{2}{y} \cdot W x} \\
& \tau \frac{0}{y}=b 1 . \sqrt{W \frac{2}{x}+W \frac{2}{y} \cdot W y x}
\end{aligned}
$$

where $b_{1}=3,210-06$.

The occurrence of currents in Paliastomi Lake and distribution of pollutants during the northeast wind were discussed.

The real relief of Paliastom Lake was used in the modeling process, to determine: the vector fields of the lake currents, the free surface of the water, and the concentration of impurities in the lake water area.

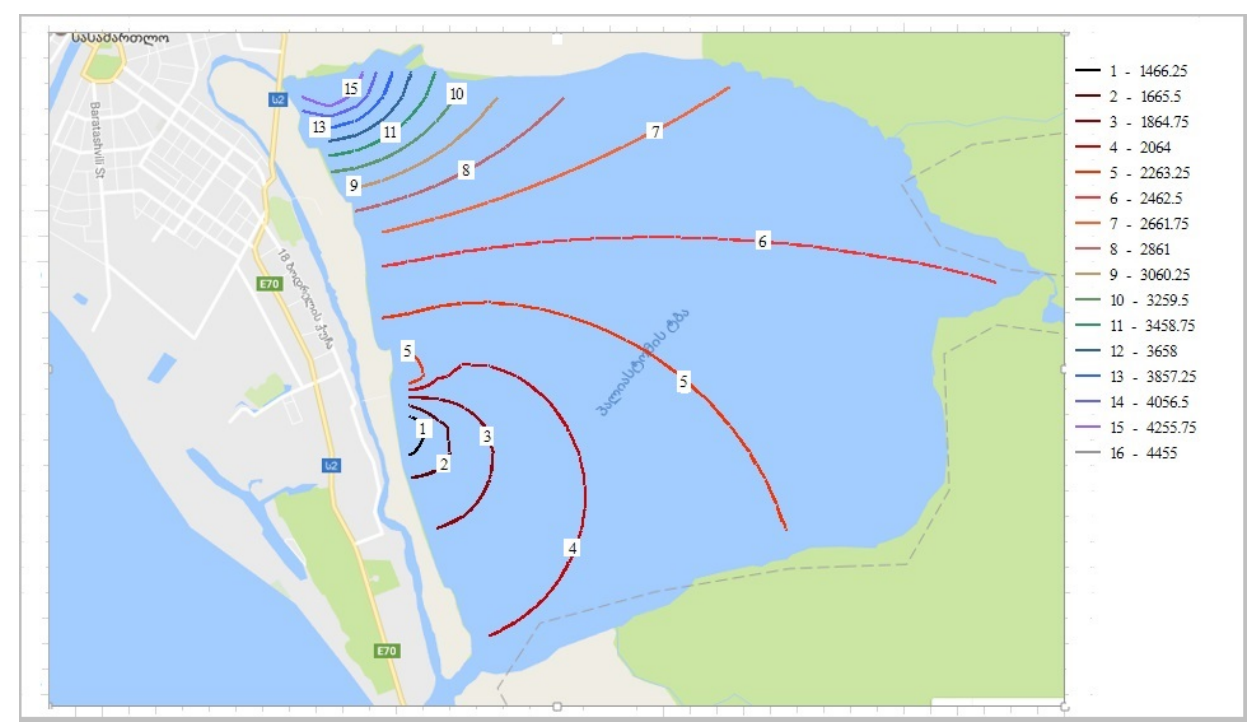

Figure 7 Common coliforms on the surface of the paliastoma lake Mathematical and numerical modeling of distributions (May 15, 2017) 
On a regular grid (size $26 \times 29$ ), experimental data were recorded. The data of the common coliforms obtained experimentally was transferred using linear interpolation by weights. The isolines on the drawing represent each value.

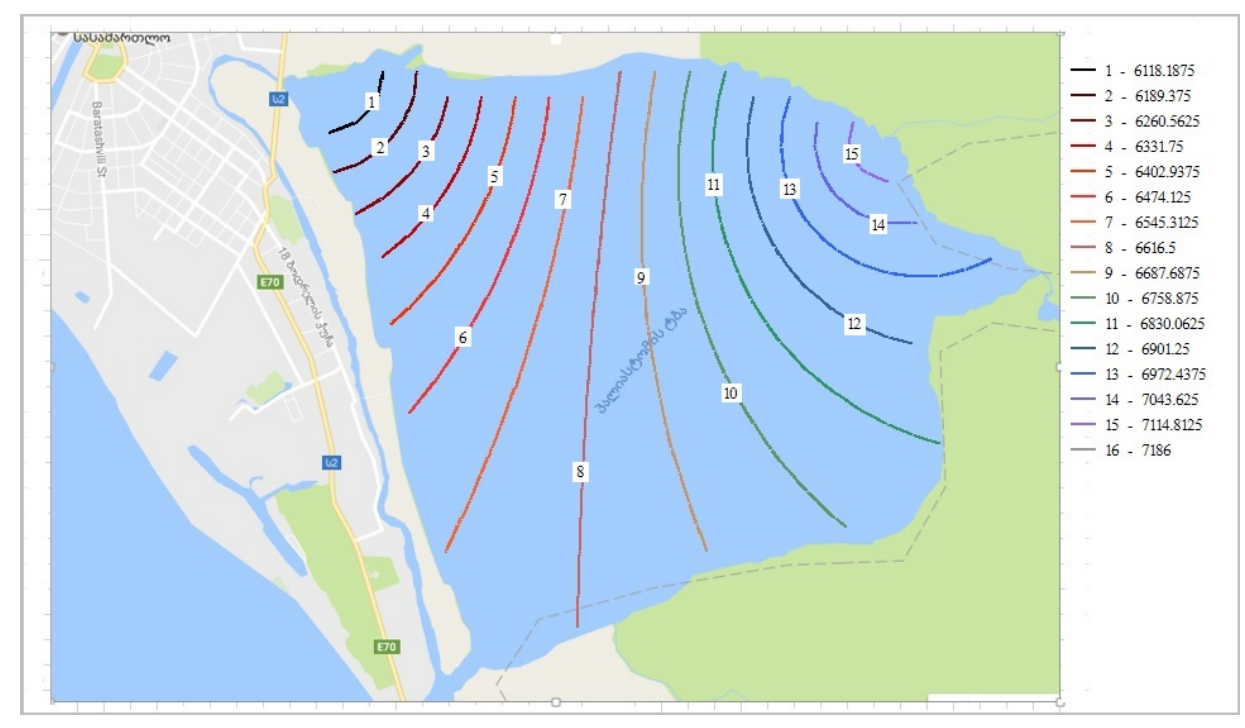

Figure 8 Common coliforms on the surface of the paliastoma lake Mathematical and numerical modeling of distributions (March 29, 2018)

Figure 7 shows the isolines of the distribution of coliforms on the surface of the Paliastom Lake obtained by modeling. The figure shows that the maximum concentration of coliforms is obtained in the south-eastern part of the lake where 3 sources of pollution are located (Ranger Base 1-3). They are 100 meters (left and right) and 500 meters away from the base of the rangers.

The 4th source of pollution is located in the northeastern part of Lake Paliastomi. Consequently, the spatial distribution of isotopes in the lake area is heterogeneous. Concentration is minimal in 2-3 areas of the base, gradually increasing in a northerly direction and reaching its maximum in the area of the 4th base. The horizontal gradients of concentrations are large in the area surrounding the bases and gradually decrease as they move away from the bases in a northerly and northeasterly direction.

Figure 8 shows the distribution of computer-modeled coliforms in the case of 2 contaminants on 29 March 2018 (airport canal and confluence of the Pichora River with Paliastom).

This model was used to determine the change in the values of the total coliforms identified by the experiment between May 15, 2017 and March 29, 2018 - April 18, 2018.

Figures 9, Figure 10 and Figure 11 show the change in concentrations of total coliforms over 24 hours. According to the drawings, there are 2 processes - diffuse and advectional transfer of common coliforms, resulting in a decrease in concentration in the maximum zone and transfer of common coliforms in the northeast direction, which coincides with the flow formed in Lake Paliastomi. The cyclonic current formed in the eastern part of the lake causes dissemination of common coliforms in the north-eastern part of the lake.

Figure 12, Figure 13 and Figure 14 show the distribution of concentrations of common coliforms at the confluence of the Phichora River and the Paliastom Lake in the case of a west wind, determined by the second experiment. 
The currents formed in Lake Paliastomi cause a change in the distribution of total coliforms, which is characterized by a decrease in concentration of $40 \mathrm{CFU} / \mathrm{ml}$ over 24 hours near the confluence of the Phichora River with Lake Paliastomi, as well as an increase of $32 \mathrm{CFU} / \mathrm{ml}$ in the vicinity of the fish farm.

We can conclude that the circulatory processes caused by turbulence in Lake Paliastomi lead to the redistribution of common coliforms throughout the water area. The distribution is uneven and especially intense in the middle of the north-western shore of the lake.

The given technology allows similar calculations to be performed for any reservoir with shallow depth. To do this, the user will only need to change the characteristics of the reservoir (horizontal dimensions, seabed relief and atmospheric wind).

The results thus obtained show that the general picture of microbiological contamination of Paliastom Lake is heterogeneous. It depends on the location of the sources of pollution, the intensity of pollution and the water currents of the lake formed by meteorological conditions.

The model proposed in the paper describes qualitatively and quantitatively well the physical process taking place in a real environment and it can be used to predict changes in the dynamic characteristics of the relevant type of reservoirs. Through this model it is possible to further solve tasks such as the rational use of environmental resources and predict the ecological status [26].

Figures of Experiment-I (15

May 2017)

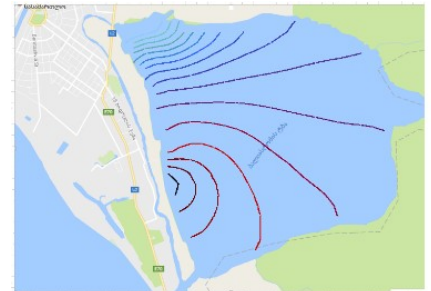

Figure 9, Dissemination of common coliforms after 6 hours

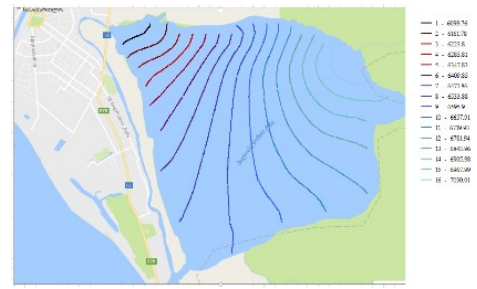

Figure 12, Dissemination of common coliforms after 6 hours

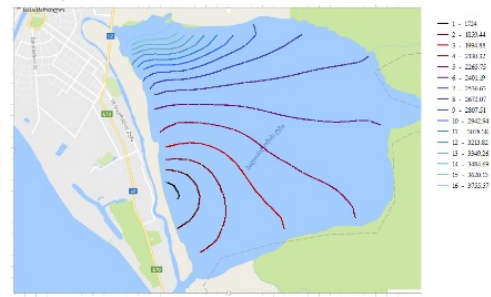

Figure 10, Dissemination of common coliforms after 12 hours

Figures of Experiment-II (18 April 2018)

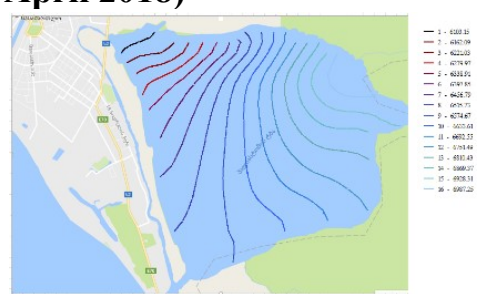

Figure 13, Dissemination of common coliforms after 12 hours

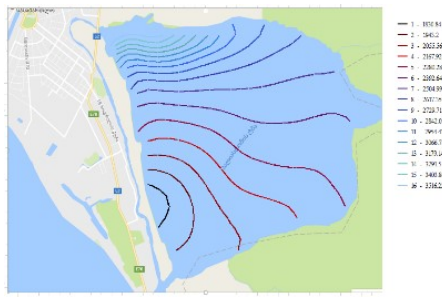

Figure 11, Dissemination of common coliforms after 24 hours

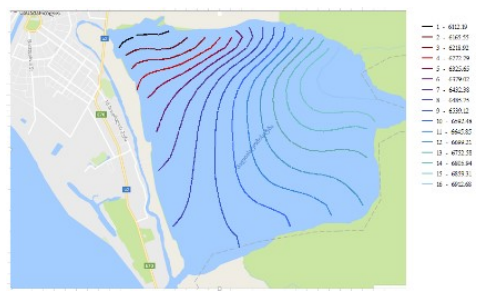

Figure 14, Dissemination of common coliforms after 24 hours

\section{Natural and artificial wetlands as main tools to treat wastewater flowing into the Lake} wetlands.

The major instruments for treating wastewater flowing into the Lake are natural and artificial 
Due to its environmental benefits and relatively minimal operational and maintenance requirements, wetlands are increasingly being used to treat wastewaters.

Different sources of information evidence an increasing use of wetlands to treat wastewaters owing to its environmental benefits and relatively low operational and maintenance requirements.

The use of wetlands for wastewater treatment is not novel, but the current expertise is gathering increased momentum in water industry due to the environmental benefits and lower operational and maintenance requirements of the given systems.

There are many different types of manufactured wetlands in use around the world, but the systems that are employed can be divided into two categories: Engineered Reedbed Systems and Integrated Constructed Wetlands.

The advantages of wastewater treatment in wetlands include environmental protection and enhancement, increased biodiversity, and carbon capture and storage.

\section{Discussion}

\section{Pollution from diffuse sources}

In addition to the direct, unpurified waste water discharges, the pollution of the Lake ecosystem is also influenced by the diffuse entries from the agricultural lands in the catchment area. In addition to the proposed measures to treat the municipal wastewater, besides the land management measures are necessary what will lead to the reduction of nutrients and pesticides flowing into the catchment areas of the tributaries. To quantify this material input, on the one hand, modeling are suitable which, in accordance with the land use and the climatic and pedological conditions in the catchment area, balance the material flows. On the other hand, a realistic image of current load can be determined by means of monitoring the springs and headwater streams.

\section{Modeling of diffuse material entries}

The basic structure of modeling the diffuse inputs follows the simple load or export coefficient approach [26]. This is to be understood as an entry at the interface of the land path to the water path (still without retention in the water bed or the accompanying wetlands):

$$
F_{N, P}=\sum_{i=1}^{n} a_{N, P} \cdot X_{i}
$$

Whereas $\mathrm{F}_{\mathrm{N}, \mathrm{P}}$ is the average nutrient input into the water body of substance $\mathrm{N}$ or $\mathrm{P}$ in $[\mathrm{kg} / \mathrm{a}], \mathrm{a}_{\mathrm{N}, \mathrm{P}, \mathrm{t}}$ are the export coefficients of $\mathrm{N}$ or $\mathrm{P}$ of land use type i $\left[\mathrm{kg} /\left(\mathrm{ha}^{*} \mathrm{a}\right)\right]$ within time $\mathrm{t}$ (for simple approaches: $\mathrm{t}=1$ year - here, the export coefficient includes already the part due to atmospheric deposition [28] and $\mathrm{X}_{\mathrm{i}}$ represents the area of land use type i [ha].

The first extension of this model approach is that the export coefficients are calculated, for example, depending on the substance concentration:

$$
a_{N, P_{i, t}}=c_{N, P_{i, t}} \cdot Q_{i, t} \cdot T D_{i, t}
$$

$\mathrm{c}_{\mathrm{N}, \mathrm{P}, \mathrm{t}}:$ substance concentration ( $\mathrm{N}$ or $\mathrm{P}$ ) of land use type $\mathrm{i}$ in time $\mathrm{t}$

$\mathrm{Q}_{\mathrm{i}, \mathrm{t}}$ : runoff on land use type $\mathrm{i}$ in time $\mathrm{t}$

$\mathrm{T}_{\mathrm{Di}, \mathrm{t}}$ : proportion of the substance $(\mathrm{N}$ or $\mathrm{P})$ transported further into the water body in time $\mathrm{t}$ 
$\mathrm{TD}_{\mathrm{i}}$ describes the retention functions. In case of soil erosion, it is the sediment supply rate. Instead of land use type $\mathrm{i}$, in more complex models so-called hydrological units are meant, which are defined by the same physiogeographical parameters. Interactions between the hydrological units (HRUs) are not taken into account.

When modeling the outputs from the areas, a fundamental distinction is made methodically (especially in conceptual models) between the land use types: the arable land, grassland, forest and settlement areas. The complexity of the summary calculations increases depending on the changes in the order of land use, forests and settled areas, grasslands and arable lands. due to the variability of land use.

\section{Monitoring of springs and headwaters}

The springs highlight the transition between groundwater and surface water. Springs dominated by near-surface groundwater (interflow), in particular, exhibit direct reactivity to material inputs in their catchment areas. Highly mobile nitrate nitrogen, as well as very mobile insecticides and their transformation products, make up this category. Due to its poor solubility, the phosphorus, which is likewise used in fertilization, is discharged via erosion in a particle-bound manner. In zones at risk of erosion, direct effects to prevent the phosphorus input can be achieved by simple measures in agriculture [29].

Numerous studies have shown that the nitrate nitrogen content in spring waters is mainly determined by three factors: hydrogeology, climate/seasonality and land use $[30 ; 31 ; 321]$. The primary determinant is land usage, particularly in semi-arid, agriculturally intensive areas (32). The actual entry into the water system can be determined via an integrated monitoring of spring waters typical of the land use pattern of the Paliastomi Lake catchment area. In order to capture the actual emissions from agriculture, the sub-basins of the springs to study must be free of the settlement influence. In addition, 1-2 springs without agriculture and settlement influence should be investigated in order to determine the background load.

At the selected spring sites, regular monitoring of nitrate contents and other basic physico-chemical water parameters over a minimum of two years is recommended. Recent studies have shown that this leads to similar results as complex continuous measuring devices [34].

In line with monitoring of springs and headwaters, new methods of monitoring of agricultural pollution of Paliastomi Lake by inflowing waters should be maintained.

From an operations standpoint, the low cost of operation of wastewater treatment in wetlands systems offers real savings in terms of energy use, demand on operations staff time and resources, as well as sludge production, handling, and disposal - all important considerations when managing the provision of effective wastewater treatment services within fiscal limits that are difficult to overcome.

In order to neutralize the contaminated sediments (e.g. heavy metals), it is necessary to remove them from the surface and bury them on the safe site, unless their high pollution endangers the water ecosystem.

\section{Conclusions}

Regular periodic inspections with minimal follow-up interventions are required for Integrated Constructed Wetland systems to maintain surface flows inside the ponds, maintain access to and from the ponds, and remove silt and organic debris that accumulates over time.

The preliminary results of microbiological and chemical analyses, combined with mathematical modeling of possible pathogenic bacteria dissemination in Paliastomi Lake, allow us to continuously monitor not only the inflowing waters of the lake, but also seasonal sources of bacterial pollution caused by migratory birds. According to the monitoring, localized spraying of Salmonella bacteriophage cocktail (SBC-1) will help limit bacterial contamination, and feeding the birds, who are potential carriers of pathogenic bacteria, food supplemented with SBC or locally selected phage cultures will promote pathogen elimination at the source, improve the habitat for local and migratory waterfowl and ensure the area's biosecurity. Furthermore, for the sake of bacterial security, all procedures will be done with the agricultural drones (Figure 13, Figure $14)$. 


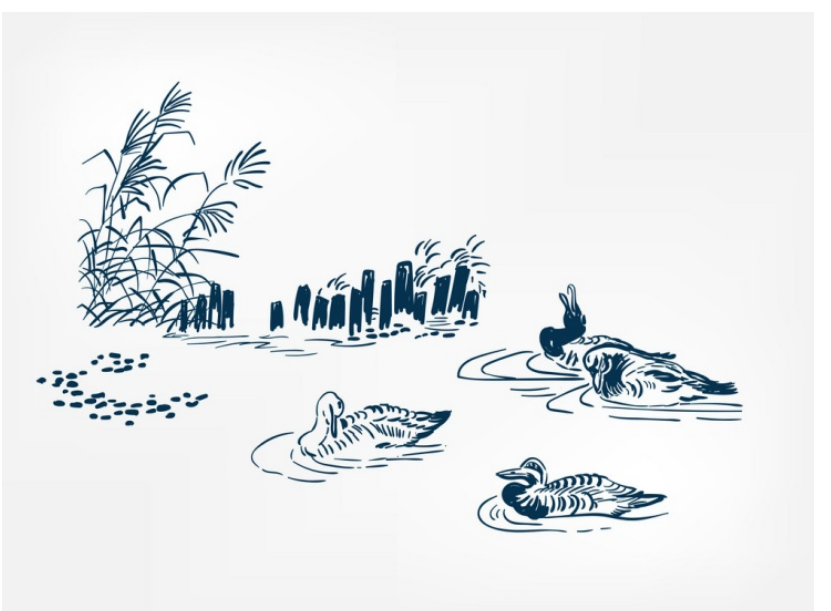

Figure 13 Waterfowl habitat

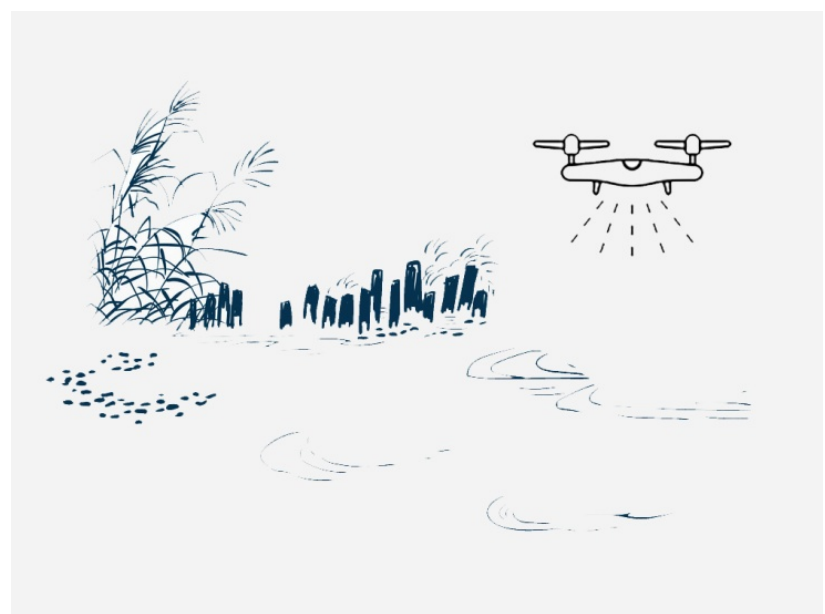

Figure 14 SBC-1 spraying by drones to eliminate microbial contamination in waterfowl habitat

\section{Methodology}

Our publication preparation team (PPT) provided study on the current state of the environment in the area adjacent to Paliastomi Lake, Kolkheti National Park determined the main sources of pollution, bird migration by seasons and fall of birds and fish. PPT has provided review on: the completed data on institutional and legal requirements and documents; the accomplished sanitary-biological studies in the given waters of the Lake; definition of dynamics of sanitary-microbial indicators in the flowing waters;

An expedition was organized on May 14-15, 2017 to carry out chemical analysis of water and seabed sediments in Paliastomi Lake. We selected and fixed GPS coordinates of 4 sites.

Paliastomi Lake water and bottom sediments were sampled, preserved, stored and transported using ISO (ISO 8288-A-86; ISO 10523-2008) standard methods to determine te chemical characteristics of water, organoleptic and chemical parameters of water, as well as bottom sediments.

In order to complete the further research tasks, we organized an expedition to study the water in te Lake and waterbed sediments of Lake Paliastom in May 14-15, 2017 and August 9-10, 2017, as well as in March and April 2018 and January and March 2019. Lake water sampling, conservation, storage, transportation, as well as analysis of water organoleptic, chemical, microbiological and chemical parameters of bed sediments were determined according to international ISO standard methods andGOST: ISO 6222:1999; ISO 8199:2018; ISO 8189:1992; ISO 9308-1:2014; GOST 18963-73.

The dissemination of chemicals and pathogenic bacteria in the water of the Lake was modeled. The following data were compiled to develop this model system:

- Hydrodynamic characteristics of water depths;

- Water level;

- Wind velocity;

- Bacterial contamination points;

- $\quad$ Bacterial monitoring;

- $\quad$ Number of common coliforms.

For computational modeling of metals and coliform dissemination in Paliastomi Lake, a twodimensional numerical model based on the system of integration by vertical integration of water movement and continuity equations was used. The program is compiled in Visual $\mathrm{C}++$. The model is based on the integration of the two-dimensional flow dynamics of THE lake dynamics and passive impedance in the water area using a modern high-resolution numerical plan. During the integration, the method of visualizing the results was applied. 


\section{ABBREVIATIONS}

AA -Association Agreement

AD- Anno Domini

BOD- Biological Oxygen Demand

BC-Bacteriophage Cocktail

CFU- Colony Forming Unit

EU -European Union

GPS- Global Positioning System

GOST- Russian: государственный стандарт, which means state standard

ICFER- International Center for Environmental Research

IBMV -Eliava Institute of Bacteriophages, Microbiology and Virology

ISO- International Standard Organization

KNP- Kolkheti National Park

MAC -Maximum Allowable Concentration

MEA- Multilateral Environmental Agreements

MAFA - Mesophilic Aerobes and Facultative Anaerobic Microorganisms

NEAP -National Environmental Action Programme

NEA- National Environmental Agency

ND- Normative Document

Ppm- part per million

tPPT- publication preparation team

SDG- Sustainable Development Goals

SBC-1 -Salmonella Bacteriophage Cocktail 


\section{References:}

1. Zurab Janelidze; HISTORY OF MODERN LANDSCAPE DEVELOPMENT OF THE COLCHIS LOWLAND COASTLINE Ivane Javakhishvili Tbilisi State University International Multidisciplinary Conference on Actual problems of landscape sciences: environments society politics APLS-ENSOPO-2019, Grant № MG-ISE-18-370 9-13 SEPTEMBER, 2019;

2. Zenkevich L.A. The Black and theAzov Sea Coasts. Moscow. Nauka, 1968 Pg. 210

3. Tobias Salathé, Ramsar Secretariat; Ramsar Advisory Mission No. 54: Georgia (2005) Mission Report Wetlands of Central Kolkheti, 2005

4. https://www.hydromet.ge/

5. HISTORY OF MODERN LANDSCAPE DEVELOPMENT OF THE COLCHIS LOWLAND COASTLINE, Zurab Janelidze Ilia State University, Tbilisi, Georgia. APLS-ENSOPO-2019, Grant № MG-ISE-18-370 9-13 SEPTEMBER, 2019

6. Directory of Azov-Black Sea Coastal Wetlands: Revised and updated. - Kyiv: Wetlands International, 2003. — 235 pp., 81 maps. — ISBN 9058829618 Published by the Black Sea Program of Wetlands International PO Box 82, Kiev-32, 01032, Ukraine, 2003 pg 60;

7. Колхидская низменность Научные предппосылки освоения Академия Наук СССР Академия Наук Грузинской ССР Институт Географии имени Вахушти Багратиони Москва « Наука« 1990, стр 35;

8. Zenkevich L.A. The Black and theAzov Sea Coasts. Moscow. Nauka, 1968 Pg. 210

9. Abramia G., Gverdtsiteli L. Eristavi D. "Assesment of Ecological situation of the lake Plaliastomi," The 5th International Scientific-Practical Conference on the topic -"The power of the field of geology is a precondition for the revival of the economy" Mineral Society of Georgia and Georgian Technical UniversityMay 29-1996; 30, pg. 8-11;

10. Eutrophication (C) European Environment Agency, 2008;

11. Uğur Parin, Şükrü Kirkan and Göksel Erbaş, Emerging Bacterial Zoonoses in Migratory Birds Open access peer-reviewed chapter 2018 DOI: 10.5772/intechopen. 72244

12. Hamer S, Lehrer E, Magle S (2012) Wild birds as sentinels for multiple zoonotic pathogens along an urban to rural gradient in greater Chicago, Illinois. Zoonoses and public health 59: 355-364.

13. Horton R, Wu G, Speed K, Kidd S, Davies R, et al. (2013) Wild birds carry similar Salmonella enterica serovar Typhimurium strains to those found in domestic animals and livestock. Res Vet Sci 95: $45-4$

14. Hubalek Z (1994) Pathogenic microorganisms associated with free-living birds (a review). Acta Scientiarum Naturalium Brno 28:1-74.

15. Roeckel, M, Martí, M.C. and Aspé, E. (1994). J. Cleaner Production 2, 31-5;

16. Фомин Г.С. Вода. Контроль химической, бактериальной и радиационной безопасности по международным стандартам. Москва. 2000, ст 839;

17. GurandaBagrationi "WaterQuality,CyanobacteriaandCyanotoxinsinTwoFreshwater Reservoirs on the Coast of Georgia" TelemarkUniversityCollegeFacultyof Art and Sciences Department of Environmental and Health Studies Hallward Eikas plass 3800 Bø, Norwayhttp://www.hit.no 2015 pg 25;

18. Колхидская низменность Научные предппосылки освоения Академия Наук СССР Академия Наук Грузинской ССР Институт Географии имени Вахушти Багратиони Москва « Наука« 1990, стр 35;

19. Middleton JH, Ambrose A (2005) Enumeration and antibiotic resistance patterns of fecal indicator organisms isolated from migratory Canada geese (Branta canadensis). J Wild Dis 41:334-341

20. Фомин Г.С. Вода. Контроль химической, бактериальной и радиационной безопасности по международным стандартам. Москва. 2000, ст 839;

21. On the approval of the norms of the quality condition of the environment.

22. Labor, Health and Social Affairs of Georgia Order of the Minister N 38 / N, N 167 / N of 16 August 2001;

23. Girgvliani A. Numerical distribution of passive impurities in the sea Modeling. VI International Scientific-Practical Conference Internet and Society, June 6-7, 2013, Kutaisi, p. 79-83;

24. Фомин Г.С. Вода. Контроль химической, бактериальной и радиационной 
безопасности по международным стандартам. Москва. 2000, ст 839;

25. On the approval of the norms of the quality condition of the environment.

26. Labor, Health and Social Affairs of Georgia Order of the Minister N 38 / N, N 167 / N of 16 August 2001 ;

27. Girgvliani A. Numerical distribution of passive impurities in the sea Modeling. VI International Scientific-Practical Conference Internet and Society, June 6-7, 2013, Kutaisi, p. 79-83;

28. Воиткевич Г.В., Кокин А.В., Мирошников А.Е., Прохоров В.Г., Справочник по геохимии, Москва, «Недра», 1990, ст. 82-83;

29. Heathwaite, A. L. (1993): Nitrogen Cycling in Surface Waters and Lakes. - In: Burt, T. P.; Heathwaite, A. L. \& Trudgill, S. T. (ed.): Nitrate: Processes, Patterns and Management. S.99-140. New York.

30. Johnes, P. J. (1996): Evaluation and management of the impact of land use change on the nitrogen and phosphorus load delivered to surface waters: the export coefficient modelling approach. - In: Journal of Hydrology. Vol. 183, S. 323-349.

31. Honecker, U., Kubiniok, J. \& G. Weber (2021): Gewässerschutz durch Bodenschutz: Kausalzusammenhänge und potenzielle Maßnahmen im Bereich der Landwirtschaft. Untersuchungen am Beispiel des Theel/Ill Einzugsgebiets im mittleren Saarland. - In: KW Korrespondenz Wasserwirtschaft, 14 Nr.1: 18-22.

32. Menció, A., Boy, M., Mas-Pla, J. 2011. Analysis of vulnerability factors that control nitrate occurrence in natural springs (Osona region, NE Spain). J. Sci. Total Environ., 409, 3049-3058.

33. Yakovlev, V., Vistivna, Y., Diadin, D., Vergeles, Y., 2015. Nitrates in springs and rivers of East Ukraine: Distribution, contamination and fluxes. Applied Geochemistry, 53, 71-78.

34. Weber, G., Kubiniok, J., 2013. Investigation of spring waters to assess the geo-ecological state of landscape and soil. Journal of Agricultural Science and Technology A 3, 592-602.

35. Boy-Roura, M., Mencio, A., Mas-Pla, J., 2013. Temporal analysis of spring water data to assess nitrate inputs in groundwater in an agricultural area (Osona NE Spain). Sci. Total Environ. 452-453, 433-445.

36. Weber, G., Honecker, U. \& J. Kubiniok (2020): Nitrate dynamics in springs and headwater streams with agricultural catchments in southwestern Germany. - In: Science of The Total Environment, Volume 722: 137858. 